\title{
THE USE OF THE SLENDERNESS COEFFICIENT IN DIAGNOSING WIND DAMAGE RISKS
}

\author{
Jerzy Skrzyszewski*, Maciej Pach
}

Department of Ecology and Silviculture, Faculty of Forestry,

University of Agriculture in Krakow, al. 29 Listopada 46, 31-425 Kraków

\section{ABSTRACT}

Violent and unpredictable winds are a phenomenon that accompanies climate change. The method of limiting the level of wind damage in forests is the cultivation of multispecies, multi-story tree stands, appropriate spatial arrangement of age classes of tree stands, and cultivation measures increasing the stability of a single tree in a stand. There are many features of a single tree that determine resistance to abiotic damage caused by violent winds. In research on the resistance of trees and stands to the damaging effects of wind and snow, the slenderness coefficient is commonly used. The aim of the study is to form: (i) an assessment of the diagnostic (predictive) value of the slenderness coefficient against other variables used in wind damage risk modelling; (ii) a review of critical values of slenderness coefficients; (iii) conclusions for silviculture (forest management) from the research on the stability of tree stands, taking into account the slenderness coefficient.

\section{KEYWORDS}

slenderness coefficient $\bullet$ windfalls $\bullet$ snow and wind damage $\bullet$ risk modelling

\section{Introduction}

The current climate changes are associated with frequent occurrence of violent and unpredictable winds (Haarsma et al. 2013). Climate warming is likely to shorten the

*ه rlskrzys@cyf-kr.edu.pl 
period during which the soil will be frozen, thus weakening the anchoring force of trees (Gregow et al. 2011). Taking the risk of wind damage into consideration is now becoming an important part of silvicultural planning (Schuck and Schelhaas 2013).

Resistance (or lack thereof) to wind damage is related to the individual characteristics of a tree and a stand, such as tree species, height, DBH, crown size, density, vertical structure, spatial arrangement of gaps, rooting depth, root system size and distribution of anchor roots as well as the presence of root or stem rot (Zajączkowski 1991, Valinger and Fridman 2011, Albrecht et al. 2012, Hanewinkel et al. 2014, Pasztor et al. 2015, Pukkala et al. 2016). Each of the listed features of a single tree (crown length, slenderness and size of the root system) individually affects the stability of the tree and can be shaped as part of the silvicultural intervention. Resistance to wind damage is also dependent on soil and orographic features, such as soil moisture (Mitchell et al. 2001), exposure to prevailing winds, inclination, altitude and on the characteristics of adjacent tree stands (age and height differences) and their spatial arrangement (Mitchell et al. 2001, Forsell et al. 2011, Albrecht et al. 2012, Hanewinkel et al. 2014 Pasztor et al. 2015).

In research on the resistance of trees and stands to the damaging effects of wind and snow, the slenderness coefficient is commonly used. This, like the stem taper which is the inverse of slenderness, is a synthetic indicator of the shape of the trunk. The slenderness coefficient for a single tree is calculated by dividing the height $(\mathrm{H})$ by the $\mathrm{DBH}(\mathrm{D})$, hence the abbreviation $\mathrm{H} / \mathrm{D}$ or H/D ratio is often given instead of the name. Most often, both quantities are expressed in the same units, but this is not always the case. Some authors adopt different units for height (meters) and DBH (centimetres). The slenderness coefficient is calculated for a stand by dividing the mean tree height by the mean $\mathrm{DBH}$, usually taking the basal area as weight function. Due to the fact that trees growing in the highest layer have a dominant influence on the stability of the stand, calculations are often performed for dominant trees (100-250 of the thickest trees on 1 hectare). Mitchell (2000) postulates the use of the slenderness coefficient as a dynamic variable that creates a time sequence (calculated on the basis of annual height and $\mathrm{DBH}$ increments). This approach to the indicator allows the observation of a tree's reaction (H/D changes) to the performed thinning treatment and provides a basis for determining the intensity and recurrence of the treatment as a result. Mitchell (2000) also indicates that the reaction of a tree to stand thinning is associated with a temporary reduction in height increment and an intensification of thickness increment. As a result, the $\mathrm{H} / \mathrm{D}$ ratio drops significantly after the procedure. The reaction of trees depends on their biosocial position and the shape of the trunk before the treatment. Also, not all trees respond equally effectively, which may be the basis for selecting trees to be removed (the ones less responsive to cutting).

The larger the $\mathrm{DBH}$ of a tree at the same height (lower H/D ratios), the greater the force required to bend its trunk. This regularity is the canon of textbook knowledge in the field of shaping the wind resistance of trees and stands (Abetz 1976 as cited: Jaworski 2013, Burschel and Huss 1997). According to Zajączkowski (1991), pines with the slenderness coefficient of 71 and 107 , at a wind speed of $17 \mathrm{~m} \cdot \mathrm{s}^{-1}$, broke at the limit bending moment of 40 and $12 \mathrm{kNm}$ respectively. A low slenderness 
coefficient is associated with a longer crown, a lower centre of gravity and a better developed root system due to a larger growth space. Therefore, trees with higher values of the slenderness coefficient (slender trees) are much more susceptible to wind damage. As the centre of gravity is lowered by lengthening the tree crown, the fracture resistance increases (the force needed to bend the trunk increases). The free development of the crown promotes the increase in $\mathrm{DBH}$ increment and the increase of stem taper (Petty and Worrell 1981). Increasing the growth space of crowns also limits their asymmetric development (Petty and Swain 1985, Valinger et al. 1994), and trees with regular crowns are less prone to swinging (e.g., under asymmetric snow loads). The occurrence of the twisting moment is also observed to a lesser extent. The roots of trees in a loosened stand more firmly anchor in the soil, which leads to an increase in resistance to windthrows (Nielsen 1995). At the same time, however, large tree crowns offer greater resistance to the pressing wind. Jelonek et al. (2013) found that the broken pines had a significantly higher slenderness coefficient, but also longer crowns and a lower centre of gravity than the trees undamaged by the wind (probably with the same slenderness coefficient - author's note). Calculations published by Konôpek (1977 as cited in Jaworski 2013) indicate that at the same wind speed $\left(70 \mathrm{~km} \cdot \mathrm{h}^{-1}\right)$ Norway spruces (Picea abies [L.] Karst) with a vertical crosssection area of 11.0 and $25.5 \mathrm{~m}^{2}$ differed in the crown load 165 and $382 \mathrm{~kg}$, respectively. Trees with large crowns are also characterized by an unfavourable proportion of the crown weight to the stem weight. Sitka spruce (Picea sitchensis (Bong.) with twice the (100\% compared to $50 \%)$ ratio of the crown mass to the trunk mass broke at the wind speed about 30\% lower (Petty and Swain 1985). In the quoted publication, trees with the same H/D and height were compared. Petty and Swan (1985) also point out that in order to break a $20 \%$ lower Sitka spruce (with the same H/D as a higher spruce), a wind speed greater of approx. $20-30 \%$ is needed. Tall trees are more at risk from wind than short trees with the same H/D because wind speed increases with distance from the ground (Galinski 1989, Peltola and Kellomäki 1993), and the bending moment increases with height (Petty and Worrell 1981, Cremer et al. 1982, Peltola and Kellomäki 1993). The given dependencies show that the assessment of the tree stability only on the basis of the slenderness coefficient is not clear.

The aim of the study is to present: (i) an assessment of the diagnostic (predictive) value of the slenderness coefficient against other variables used in wind damage risk modelling; (ii) a review of critical values of slenderness coefficients; (iii) conclusions for silviculture (forest management) from the research on the stability of tree stands, taking into account the slenderness coefficient.

\section{Significance of the slenderness coefficient in risk diagnostics}

The slenderness coefficient is used in two purposes: (i) in identifying hazards from abiotic damage and (ii) as one of the independent variables in modelling of these hazards. 
In some publications, the authors use the slenderness coefficient as a measure of trees/ stands. They formulate conclusions and assessments as to the validity of the stand tending, assuming that some $\mathrm{H} / \mathrm{D}$ ratios will be more resistant to wind and snow. Publications using the slenderness ratio as the only and absolute measure of tree stand stability also concern species that are exotic to Europe (Adeyemi and Adesoye 2016). In order to assess whether the features of a tree/stand indicate the "safe level" of the slenderness coefficient, the relationships (correlations) between the features of the tree (e.g., tree diameter at breast height $(\mathrm{DBH})$, height, crown length and age), the stand (e.g., stand density level, species composition, and site index values) and the slenderness coefficient are investigated (Rymer-Dudzińska 1992, Wang et al. 1998, Wilson and Oliver 2000, Orzeł 2007, Kaźmierczak at al. 2008, Korzeniewicz et al. 2016, 2019). A similar idea gives reasons for the creation of stand density management diagrams (SDMD), created on the basis of regression relationships between various stand characteristics, on the scale of the entire production period (rotation age) (Castedo-Dorado et al. 2009, Vacchiano et al. 2013, Meng et al. 2017). The diagrams allow to determine the correlation between the variables related to the production of wood (e.g., quadratic mean diameter, stand merchantable volume) and the number of trees per area unit. They allow to assess the effects of a given intensity of cuts and their intervals, taking into account the age of the stand. The diagrams also allow to determine the average slenderness coefficient of the stand (e.g., for a given density) or contain isolines for stand slenderness coefficient and the zones of stability (e.g., stable, intermediate, unstable zone). SDMD diagrams allow foresters to compare different thinning schedules (and intensity and intervals) that take into account both wood production and the risk of wind or snow damage. In the mentioned methods (studies) it is assumed that H/D is a sufficient measure of stability. The aim of such research is to determine the slenderness coefficient interpreted as the level of wind damage threat to the stand. However, it was not always an element of the cited papers to verify, in the specific cases covered by the research, whether there is indeed a linear relationship between the slenderness coefficient and resistance to wind damage of stands, which were often of different age, density or structure.

Another methodological approach is to create models that allow to predict the fact of wind damage or the probability of its occurrence. In these models, the slenderness coefficient is one of many variables. Predictors used in these empirical studies have included: variables concerning the topographic situation (Mitchell et al. 2001, Albrecht et al. 2012, Hanewinkel et al. 2014, Pasztor et al. 2015); variables referring to the soil and site conditions (Mitchell et al. 2001); and variables describing stand- and tree-level characteristics such as mean basal area (Valinger and Fridman 2011, Albrecht et al. 2012, Pasztor et al. 2015), density (Pukkala et al. 2016), tree size (height, diameter) (Martín-Alcón et al. 2010, Albrecht et al. 2012, Pukkala et al. 2016), stand structure (Hanewinkel et al. 2014, Pukkala et al. 2016), dominant species and species diversity (Valinger and Fridman 2011, Albrecht et al. 2012, Pasztor et al. 2015). The analysis of the effectiveness, measures of fit, predictive and classification capabilities of these models shows that the slenderness coefficient as a single variable often has a relatively small value as an independent variable. 
Pukkala et al. (2016) studied the features of damaged and undamaged single trees in stands managed with various methods (according to different principles): control (no cuttings); dimension cutting; selective high thinning of previously high-thinned stand; low thinning of previously low-thinned stand; high thinning of previously low-thinned stand; thinning of a mature previously low-thinned stand; regenerative shelterwood cut. Dimension cutting and single-tree selection methods represented continuous cover forestry. In this study authors modelled the probability of wind throw as a function of thinning type, time since previous cutting, characteristics of the subject tree and stand, and shelter provided by adjacent upwind stands. The authors used the following as variables: diameter $(\mathrm{cm})$, height $(\mathrm{m}), \mathrm{H} / \mathrm{D}$ ratio, basal area $\left(\mathrm{m}^{2} \cdot \mathrm{ha}^{-1}\right)$, shelter basal area $\left(\mathrm{m}^{2} \cdot \mathrm{ha}^{-1}\right)$ - weighted (proportions of the directions of damaging winds as weights), basal area of adjacent upwind (from windward) plots, time since cutting (years). Slender (high H/D) trees had a higher probability of wind throw (increasing $\mathrm{H} / \mathrm{D}$ ratio increases the probability of damage). In the cited studies, the variable (slenderness coefficient) turned out to be useful, but only in interaction with a specific level of basal area and DBH. The level of damage in the stands managed with the methods represented by continuous cover forestry was lower.

In the publication by Martín-Alcón et al. (2010), for snow and wind damage modelling (as a measure the percentage of trees presenting damages was used) the following tree stand features were applied: tree canopy cover $(\%)$, density (trees $\left.\cdot \mathrm{ha}^{-1}\right)$, basal area $\left(\mathrm{m}^{2} \cdot \mathrm{ha}^{-1}\right)$, non-coniferous basal area $(\%)$, quadratic mean diameter $(\mathrm{cm})$, coefficient of variation of the diameter at breast height, mean height $(\mathrm{m})$, dominant height $(\mathrm{m})$, plot average slenderness coefficient $\left(\mathrm{m} \cdot \mathrm{cm}^{-1}\right)$, dominant strata slenderness coefficient $(\mathrm{m}$ $\cdot \mathrm{cm}^{-1}$ ). The variables were supplemented with site features: elevation (m a.s.l.), slope (\%), soil $\mathrm{pH}$. Plot average slenderness coefficient was calculated as a ratio between the average tree height $(\mathrm{m})$ and the average tree diameter $(\mathrm{cm})$. Dominant strata slenderness coefficient was defined as the relation between the height of the dominant trees $(\mathrm{m})$ and the quadratic mean diameter within a plot $(\mathrm{cm})$. Both the plot average and the dominant strata slenderness coefficient influenced the prediction of the percentage of damaged trees in the stand. The higher the coefficient values, the greater the threat. Ultimately, in the model proposed by the authors (Martín-Alcón et al. 2010), the dominant strata slenderness coefficient divided by the basal area was taken into account. It was concluded that for a given slenderness coefficient, the damage increased strongly in stands with a lower density, which was especially evident in stands with the basal area of less than $15 \mathrm{~m}^{2} \cdot \mathrm{ha}^{-1}$. In loosened stands, the resistance of single trees is very significant. For in stands with full closure, the trees support each other. The percentage of trees damaged in the stand by wind and snow strongly decreases with a higher basal area for a given dominant strata slenderness coefficient. The authors estimate that slenderness alone is not a good indicator of stand stability, because an indicator of the effect of mutual support of trees within the stand is also needed (Martín-Alcón et al. 2010). Other authors express this opinion as well (Schütz et al. 2006, Schelhaas et al. 2007).

In the publication by Albrecht et al. (2012) four steps involved in statistical modelling of empirical storm damage data (hurdle model) was presented. The following variable

acta silvestria $\bullet$ vol. LVII • 2020 • 7-24 
groups were used: tree species, tree/stand dimension, H/D ratio, stand density, silvicultural intervention, site/soil, historic stand density, orography/wind data. The aggregate number of tested predictor variables is 47 variables. In the " $\mathrm{H} / \mathrm{D}$ ratio" variables group, the following slenderness coefficients calculated for a stand were tested: mean stand $\mathrm{H} / \mathrm{D}$ ratio $(\mathrm{Hg} / \mathrm{Dg}$, g - basal area); dominant stand H100/D100 ratio (mean quadratic height and diameter of 100 thickest trees per ha); relative H100/D100 ratio (value for a given stand divided by the average for all stands, in height classes of every $5 \mathrm{~m}$ ). In the scale of a single tree, the tree $\mathrm{H} / \mathrm{D}$ ratio and relative tree $\mathrm{H} / \mathrm{D}$ ratio were used. In calculations, height was expressed in $(\mathrm{m})$ and $\mathrm{DBH}$ in $(\mathrm{cm})$. Summarized weight of "H/D ratio" predictor group for the analysis of storm damage was 15\% (all variable groups added up to $100 \%)$. Among the variables of the "H/D ratio" group, only the relative H100/D100 ratio variable was a statistically significant component of the models. The authors stated, however, that: "signal obtained from our dataset for the relative H/D ratio was partly contradictory". In the summary of the work, the authors did not distinguish variables from the "H/D ratio" group among the variables useful for modelling the predisposition of a stand to wind damage. In a discussion to this publication, a critical assessment of appropriability of the slenderness coefficient as the wind damage predictor was included. It was explained that in the first half of the 20th century, high-density stands were cultivated and the slenderness coefficients (H/D ratio) were high. Currently, stands grown in low tree density (lower H/D ratios) are preferred. In the first half of the 20th century, however, such an increase in catastrophic wind damage was not observed. Introduction of data from the first half of the 20th century (high H/D and no hurricanes) and data from the second half of this century (low H/D and frequent hurricanes) into the models leads to false correlations. Moreover, trees grow quickly in height at a young age, and with age, the growth in height rate decreases and the H/D ratio decreases, so the variable height must be considered simultaneously. It should also be remembered that in more fertile habitats with higher site index, slenderness coefficients are higher and reach their maximum values earlier (they culminate earlier).

In the summary of research by Oliverir (1987), it was found that trees with low H/D ratios have large crowns that offer greater resistance to the winds. A tampered trunk (lower H/D ratios) is more resistant to breaking, but the bending moment at the same wind speed will be greater for these trees. Taking into account the above-mentioned factors, the author of the quoted publication does not recommend using the H/D ratio as a single variable that is a predictor of resistance to wind damage. In the summary of the study results, the author states that the most important factors influencing the risk of wind damage are: tree species affiliation and stand height. The data on past thinning and final cuttings explain the damage predisposition of the stand better than for example stand density, soil and site conditions or topographic variables. Removal of dominant trees is detrimental to the stability of the stand and such cuts should be avoided, especially in spruce stands. However, the removal of dominant trees during regeneration cuttings, e.g., taking into account the target $\mathrm{DBH}$, is inevitable.

Schütz et al. (2006) studied the relationship between damage indices after LOTHAR (dependent variable) and the traits of damaged stands. For spruce stands, the follow- 
ing variables were taken into account: aspect classes, top height, stand closure before LOTHAR, wind turbulence level, slenderness coefficient, crown proportions, elevation a.s.l., thinning intensity, slope, wind speed. Only the first 3 variables were included in the regression model. The slenderness coefficient was a nonsignificant variable. In the beech stands (Fagus silvatica L.), the following variables were of significant importance in the regression model: wind speed and year after last thinning. Also, in this case, the slenderness coefficient was a nonsignificant variable. In addition, the authors found that the admixture of approximately $10 \%$ of deciduous tree species or wind-resistant conifers, such as Douglas fir (Pseudotsuga menziesii (Mirb.) Franco), decreased the sensitivity of spruce stands to wind damage more than three times. On wind-exposed aspects the damage was more than twice the average. Forest stands on hillsides with a slope above $50 \%$ were six times more exposed to wind than hillsides with a slope below 20\%. Based on their own research and the cited literature, the authors suggest that the presence of gaps and the total length of the borders with neighbouring stands increases the susceptibility to damage. The risk of destabilisation increases significantly with the width of the gaps from 1 to 2 times greater than the height of the dominant trees (Gardiner et al. 1997). Each hurricane creates new gaps and also enlarges existing ones. The enlargement of gaps occurs more often than the creation of new gaps (Quine 2003). The authors (Schütz et al. 2006) recommend stabilising thinning at an early age (up to 60 for spruce and up to 75 for beech).

In the publication by Díaz-Yáñez et al. (2019) variables related to site: altitude (m), relief, latitude (m), slope (\%) and soil type and to stand features: species, mean diameter $(\mathrm{cm})$, dominant height $(\mathrm{m})$, slenderness $\left(\mathrm{m} \cdot \mathrm{cm}^{-1}\right)$, density (trees $\cdot$ ha $\left.{ }^{-1}\right)$, Gini index, Shannon coefficient were used. 313 models were created, indicating the impact of various variables on the probability (forecast) of wind damage and the interactions between the variables. The variables most strongly associated with the occurrence of damage are: latitude, altitude and slope (related to site and location), and tree density, mean diameter and height (related to forest characteristics). It was found that stand dominant height is a key variable in explaining damage probability. Stand slenderness has a limited effect. In the best models (in terms of predictions), the slenderness coefficient contributed to explaining the probability of damages below 10\%. Increasing slenderness did not affect the probability of damage occurring in any of the analysed forest types. Research results indicate that height explains the greater part of the probability of damage, while slenderness has a very limited effect. The authors explain it with the fact that slenderness provides information about stability at the tree level, not at the stand level, which may explain the lack of influence on the models presented in the study. In previous studies (Díaz-Yáñez et al. 2017), they also found that stand slenderness itself is not a good predictor for determining the level of resistance to snow and wind damage, although it turned out to be one of the important variables in determining the intensity and type of damage in spruce and mixed stands.

In the publication by Bergeron et al. (2009), the critical bending moment of Picea mariana (Mill.) B.S.P trees in stands of regular and irregular structures was defined. The relationship between bending moment and tree and stand characteristics was

acta silvestria $\bullet$ vol. LVII • 2020 • 7-24 
calculated. The following variables were included: stem mass, average spacing between trees and H/D ratio. Stem mass was the most useful and significant explanatory variable. The slenderness coefficient was important only when the sample included not only broken and overturned trees, but also snapped trees. Stands with irregular structures were not found to be more resistant to wind than regular stands. In the case of identical tree features (stem mass and H/D ratio), no increase in resistance was found in stands with a different structure, taking into account both stem breakage and overturning. The authors state, however, that in irregular stands, trees may have more tampered stems, which increases their resistance to wind. They recommend not to keep trees that are too old due to the presence and development of decay. They also recommend promoting trees with a low slenderness coefficient and frequent cutting intervals.

Peltola et al. (1997) point to the interaction between the slenderness coefficient, snow load and wind speed related to damage leading to breaking or uprooting of a single tree. Scots pine (Pinus silvestris L.) and Norway spruce with H/D of 120 were damaged at a short-term snow load of $60 \mathrm{~kg} \cdot \mathrm{m}^{-2}$ and a wind speed of $9 \mathrm{~m} \cdot \mathrm{s}^{-1}$. Similar damage was recorded for a long-term snow load of $20-40 \mathrm{~kg} \cdot \mathrm{m}^{-2}$. Long-term snow load with a mass of $60 \mathrm{~kg} \cdot \mathrm{m}^{-2}$ caused breakage of trees with $\mathrm{H} / \mathrm{D}$ of 100 . The authors found that pines and spruces with a slenderness coefficient of 120 are more liable to being uprooted than to stem breakage with a short-term snow load of 20, 40 and $60 \mathrm{~kg}$ $\cdot \mathrm{m}^{-2}$ (less wind speed was needed to cause this type of damage). The risk of uprooting was more likely than stem breakage after heavy snowfall in late autumn in unfrozen soil conditions. Pines and spruces with an H/D of 80 (grown in a loose spacing and/or heavily thinned) were not exposed to a high risk of snow damage. The authors explain that with a low slenderness coefficient, snow would be dislodged from the tree crowns by gusts of wind. In the publication by Päätalo et al. (1999), it was specified that low wind speeds (below $9 \mathrm{~m} \cdot \mathrm{s}^{-1}$ ) and significant snow loads increase the risk of damage, while higher wind speeds remove snow from the crowns.

In the publication by Päätalo et al. (1999), regression models were used to predict the critical wind speed that would cause uprooting or windfalls. The equations used stand density, snow load and distance from stand edge variables and characteristics of a single tree, such as: $\mathrm{DBH}$ and height as well as length, width and area of the crown; the length and width of the root system; the mass of the trunk, roots and crown. In the case of these studies, only the slenderness coefficient was of significant predictive importance among the characteristics of a single tree.

\section{Critical H/D ratios}

Due to the widespread use of the slenderness coefficient as a measure (indicator) of resistance to wind damage, many authors provide its desired/critical values. In Germany, Abetz (1987) recommended a slenderness coefficient of around 80 as appropriate for Norway spruce. In general, the value of 80 can be considered as textbook value. In the textbook by Burschel and Huss (1997), the authors adopted the following 
scale of values for conifers: very unstable $(\mathrm{H} / \mathrm{D}>100)$, unstable (H/D 80-100), stable $(\mathrm{H} / \mathrm{D}<80)$, trees growing singly $(\mathrm{H} / \mathrm{D}<45)$. In the studies by Thomasius et al. (1986 as cited: Wilson and Oliver 2000), conducted in Norway spruce stands, it was found that at $80 \%$ canopy closure on dry soils (ensuring good tree anchorage), average H/D ratios for stands may exceed 100, but they must be below 100 in wet soils (weaker tree anchorage). At 40\% density, the H/D ratios must be below 100 (dry soils) and below 80 (wet soils). The presence of root or butt rot in the stand required lower H/D ratios to maintain stability. Johann (1981) and Rottmann (1985 as cited: Peltola et al. 1997) suggest that Norway spruces and Scots pines with slenderness coefficient of 90-100 are prone to damage if the crown is very short. Trees with H/D of 70 or below are not exposed to snow damage (Rottmann 1985 as cited: Peltola et al. 1997). Becquey i RiouNivert (1987 as cited: Wilson and Oliver 2000) defined the H/D range increasing the stability of the Norway spruce stand in France after the hurricane of 1982. For stand heights of 20 to $30 \mathrm{~m}$, the "unstable" mean H/D ratios were above 90; stable stands had mean H/D ratios below 60. For Douglas fir from the territory of the Netherlands, it is recommended to keep the slenderness coefficient not higher than 50-60 as safe for this species at medium wind speeds (Faber 1975). The model proposed by Lohmander and Helles (1987) predicted 100\% damage probability for Douglas fir with H/D ratios greater than 67 and heights greater than $25 \mathrm{~m}$ (after a very strong storm in Denmark in 1981). The probability of damage was reduced to $50 \%$ when the trees were $20 \mathrm{~m}$ tall (with the same H/D). Wind damage probabilities decreased dramatically as the H/D ratios approached 50. Cremer et al. (1982) found that the wind threat for Pinus radiata $\mathrm{D}$. Don is high when $\mathrm{H} / \mathrm{D}$ is $90-100$ (for 200 dominating trees on the area of 1 hectare). Directly after the performance of thinning, the safe H/D border decreased to 85 . Minimal damage occurred in stands with $\mathrm{H} / \mathrm{D}$ below 80 . P. radiata growing with no canopy closure were undamaged and had H/D of 38 .

\section{Summary}

Methods for wind and snow damage level limitation are cultivating multispecies and multigenerational stands, correct spatial distribution of stands of different age and height in regard to each other and silvicultural measures increasing the stability of a single tree in a stand. One of measures of this stability is the slenderness coefficient. The stands that require thinning to improve stability are usually single-storey and consist of trees with little stability (short crowns, high H/D ratio, high centre of gravity). The treatments provide stand endurance in the long term, while increasing the risk immediately after their implementation. The destabilisation effect after the treatment is due to an increase in the roughness of the crown storey (gaps appear, provoking the emergence of turbulence), and the lack of support for neighbouring and not very stable trees. The threat is temporary, as the stand becomes compact again after 2-8 years (Cremer et al. 1982). Mostly threatened are medium-aged condense stands in which too radical (strong) thinning was performed. Strong thinning in such stands leads to a temporary increase of wind damage probability 
(Cremer et al. 1982, Hanewinkel et al. 2014). Strong thinning is to be avoided, especially in high-risk areas and trees of high H/D ratio are to be removed. Strong thinning is to be avoided especially in areas with high snow precipitation (Valinger et al. 1994). A strategy should be adopted to strengthen the factors determining the stability of a single tree (slenderness, crown length and shape) without permanently breaking the canopy closure. In even-aged forests of high damage risk, very early and frequent improvement cuttings are to be performed. Treatments should begin with stronger cuts at a very young age, gradually reducing their intensity with age (Martín-Alcón et al. 2010). Negligence during the first non-commercial and commercial thinnings cannot be compensated for with subsequent strong treatments (Burschel and Huss 1997). Authors in the textbook (Burschel and Huss 1997) formulated this problem in the form of a very convincing care program for Norway spruce (Gesichtspunkte für die Erziehung von Fichtenbeständen im praktischen Betrieb). An alternative to cuts reducing density can be a looser planting spacing, approx. 2500 pcs. ha ${ }^{-1}$ of Norway spruce seedlings (Chroust 1986 as cited: Jaworski 2013). Díaz-Yáñez et al. (2019) state that increasing the density to the level of 2000 pcs. $\mathrm{ha}^{-1}$ increased the probability of damage occurrence in all the forest types analysed by these authors. Safe strategies include looser planting spacing, strong cuts at a young age (sapling and young pole stand), and in neglected stands, very weak cuts in many entries. Wilson and Oliver (2000) studied the effect of initial planting densities and early thinning on the stability of Douglas fir stands (Pseudotsuga menziesii (Mirb.) Franco) taking height to diameter ratios (H/D) in the 250 dominant trees as a measure of wind resistance. They found that $\mathrm{H} / \mathrm{D}$ ratios can be decreased and stability increased by drastically reducing planting density or by performing very early thinning. Due to the low planting density, the thinning procedure can be carried out later. Thinning at a later age does not sufficiently reduce the H/D ratio. Higher number of seedlings require very early thinning treatments that must not be belated. In the study, planting density of 500 to 3500 pcs. ha ${ }^{-1}$ was analysed. The authors found that stands grown after planting more than 1000 trees $\mathrm{ha}^{-1}$ require at least one thinning to maintain the $\mathrm{H} / \mathrm{D}$ ratios in a moderate range $(<85)$ before they reach $30 \mathrm{~m}$ in height. Increasing the planting density to 2000 trees ha $\mathrm{h}^{-1}$ and above, additionally reduces the time span (management flexibility) over which thinning is effective. This effect is intensified with the increase in habitat productivity. In order to avoid weed competition and reduction in wood quality (e.g. large branches, juvenile wood core, and low percentage latewood), the authors propose to supplement the species composition of stands with species that will not affect the dominant Douglas fir in the future (Tsuga heterophylla and Thuja plicata). The authors conclude that there is no single $\mathrm{H} / \mathrm{D}$ ratio that guarantees stability. It depends on the strength of the wind. Moreover, the acceptance of a given H/D ratio depends on the choice of the dominant, preferred forest function. We are not able to completely eliminate the risk of wind and lowering the H/D leads to a reduction in the production value. Intensifying the productive functions of the forest will always lead to an increased risk from wind. On the basis of own research (Skrzyszewski 1993) it was found that the promotion of low slenderness coefficient (less than 80) during the thinning of trees (Norway spruce) led to the formation of stands composed of low-branched trees with a large share of ingrown knots and with a very 
tampered trunk and wide rings which, in coniferous species, results in low mechanical strength and reduced durability of the wood. These features significantly reduce the value of the produced raw material. Subordinating the silvicultural goal to the stability improvement of stands may therefore be associated with a reduction in their value. It also requires higher costs related to the possible pruning of trees.

An alternative may be the all-aged stand (selection structure) management (Griess and Knoke 2011, Pukkala et al. 2016). Multi-storey forests (uneven-aged stand structure) are widely considered to be less vulnerable to wind damage than single-storey stands of the same density (Dobbertin 2002, Jaworski 2013, Hanewinkel et al. 2014). It was found that continuous cover management reduces wind damage compared to even-aged stands (Pukkala et al. 2016). Complex structure of a stand was associated with a low probability of windbreaks, in contrast to even-aged stands. It was also found by Martín-Alcón et al. (2010) that the vertical structure of a stand was particularly important for determining the endurance of pine stands: the stands of even height showed higher sensitivity to wind and snow. The low damage values found in stands with different tree heights can be partly explained by the lower percentage of tall trees (Martín-Alcón et al. 2010). On the other hand, in even-aged stands, adjacent trees can support each other, and the canopy surface is more aerodynamic (less rough), especially if the height difference between individuals is small (Quine et al. 1995). Whereas in the stands of different ages, the tallest trees do not have the support of their neighbours (Drouineau et al. 2000), as well as in the low-density even-aged stands, which are more exposed to violent winds than the dense stands. In the study by Pukkala et al. (2016), very dense uncut stands were marked by a very low wind damage probability. The lack of mutual support in selection forests, however, may be compensated for by high resistance at the level of a single tree, because trees in forests with such a structure usually have higher stem taper (Kenk and Guehne 2001, Mason 2002, Dhôthe 2005). Continuous cover forests are also characterised by a shorter aggregate border length of adjacent single-storey stands of different heights (Zeng et al. 2007). Under given conditions, the impact of the differentiation of the height structure may depend on the species composition of the stand e.g., the study by Díaz-Yáñez et al. (2019) showed that more heterogeneous stand structures reduce the damage probability in stands dominated by birch but not in ones dominated by spruce. In previous studies (Díaz-Yáñez et al. 2017), it was found, however, that spruce stands with more heterogenous structures are less prone to suffer breakage of trees. Measures to change the single-generation structure to the continuous cover one pose a threat to single dominant trees if these are not adapted to the increased wind load (Mason 2002, Martín-Alcón et al. 2010). Structure transformation requires a preparatory period to improve stability. Therefore, treatments aimed at modifying the structure of the stand (e.g., reducing the density of the upper storey of the stand) should be applied carefully, gradually over a long period of time, preferably in the early stages when stand heights are low.

Analyses by Pukkala et al. (2016) showed that the riskiest final cuttings (related to the stand renewal) were shelterwood cuttings preceded by delicate thinnings. Stands

acta silvestria $\bullet$ vol. LVII • 2020 • 7-24 
were the most prone to wind damage directly after the thinnings. The cuts in which the probability of windfalls was the lowest were strong selective thinnings in uneven-aged stands and cuts according to the target $\mathrm{DBH}$. Increasing the tree height, increasing the $\mathrm{H} / \mathrm{D}$ ratio, reducing the basal area of the stand and reducing the basal area of adjacent stands from the windward side increased the probability of wind damage.

Another way to reduce the risk of wind damage is to minimize the differences in height between adjacent stands (Heinonen et al. 2009, 2011) by creating a sequence of stands of increasing height in accordance with the wind direction (Jaworski 2013). On the other hand, as stated by Heinonen et al. (2009), the risk indicator determined on the basis of the direction and intensity of the wind is a stronger factor influencing the damage than the management actions focusing on minimising the differences in height between neighbouring stands. It is also recommended to apply narrow clearcutting belt on the border of a mature (before its removal) and young stand when the former is located from the windward position (clearcutting to create a protective wall around the stand) or to apply fragmentation of large complexes in order to create the edges of stands (clearcutting of a belt of ca. $15 \mathrm{~m}$ in width) (Jaworski 2013). Sometimes it is also recommended to lower the rotation length of isolated stands and raise it for stands protecting other endangered stands from the windward side (Meilby i in. 2001). This concept is also one of the ways to protect stands regenerated with the Gayer regeneration method (the principle of leaving the protective belt on the windward side protecting the regeneration zones) (Jaworski 2018).

In Europe, in the forests of the temperate zone, spruce stands are particularly endangered (Heinonen et al. 2009, Albrecht et al. 2012). Wind damage is of great economic importance in pine stands due to the high proportion of these stands in terms of their area. Evergreen coniferous forests retain their assimilation apparatus in winter and are more exposed to wind during this period (Hanewinkel et al. 2008). The threat to spruce (coniferous) stands is exacerbated by bark beetle gradations (Jönsson and Bärring 2011, Marini et al. 2013). The threat to pine is magnified by the asymmetric crown development, especially with the combined effect of snow load on the crown and wind action (Kangas 1959 and Perttilaä 1987 as cited: Päätalo et al. 1999). The models by Pasztor et al. (2015) showed that, inter alia, reducing the share of Norway spruce, limiting the age of the stand and reducing density may reduce the risk and the expected intensity of wind damage.

The value of the slenderness coefficient is the result (effect, derivative) of the specific structure of the stand, its age (height) and degree of density, as well as treatments performed in the past. Many publications cited in this study questioned the $\mathrm{H} / \mathrm{D}$ ratio as an objective measure of stand resistance to wind. However, this does not discredit its diagnostic value as a synthetic measure representing a complex of factors determining the stability of a tree or a stand. The publications cited earlier indicate, however, that the slenderness coefficient should be analysed in a complex with other variables (species composition, stand structure and density as well as habitat, soil moisture, exposure, slope, height above sea level, age and the height of adjacent stands). 


\section{References}

Abetz P. 1976. Beiträge zum Baumwachstum. Der h/d-Wert - mehr als ein Schlankheitsgrad! Forst-u. Holzwirt Jg. 31 (19).

Abetz P. 1987. Why the crop tree aligned thinning system (ZB-Df) increases the stability and productivity of stands. In: Development of thinning systems to reduce stand damages. Proceedings of IUFRO Group S1.05 - 05, June 1987, Sweden. Ed. H. Knutell. Department of Operational Efficiency, Faculty of Forestry, Swedish University of Agricultural Sciences, Garpenberg, Sweden, 35-42.

Adeyemi A.A., Adesoye P.O. 2016. Tree Slenderness Coefficient and Percent Canopy Cover in Oban Group Forest, Nigeria. Journal of Natural Sciences Research, 6, 4: 9-17.

Albrecht A., Hanewinkel M., Bauhus J., Kohnle U. 2012. How does silviculture affect storm damage in forests of south-western Germany? Results from empirical modelling based on long-term observations. Eur. J. Forest. Res., 131: 229-247. https://doi.org/10.1007/s10342-010-0432-x.

Becquey J., Riou-Nivert P. 1987. L'existence de zones de stabilité des peuplements. Conséquences sur la gestion. Rev. For. Fr., 39: 323-334.

Bergeron C., Ruel J.-C., Élie J.-G., Mitchell S.J. 2009. Root anchorage and stem strength of black spruce (Picea mariana) trees in regular and irregular stands. Forestry, 82, 1: 29-41. doi: 10.1093 /forestry/cpn035.

Burschel P., Huss J. 1997. Grundriss des Waldbaus. Parey Buchverlag, Berlin.

Castedo-Dorado F., Crecente-Campo F., Álvarez-Álvarez P., Barrio-Anta M. 2009. Development of a stand density management diagram for radiata pine stands including assessment of stand stability. Forestry, 82, 1: 1-16. doi: 10.1093/forestry/cpm032.

Chroust L. 1986. Porostni výchovou ke zvýšeni odolnosti smrkových porostů. Les. Pr., 65 (8).

Cremer K.W., Borough C.J., McKinnel F.H., Carter P.R. 1982. Effects of stocking and thinning on wind damage in plantations. N. Z. J. For. Sci., 12: 244-268.

Dhôthe J.F. 2005. Implication of forest diversity for the resistance to strong winds. In: Forest diversity and function. Eds. M. Scherer-Lorenzen, C. Körner, E.D. Schulze. Springer, Berlin.

Díaz-Yáñez O., Mola-Yudego B., Ramón González-Olabarria J.R. 2019. Modelling damage occurrence by snow and wind in forest ecosystems. Ecological Modelling, 408, https://doi. org/10.1016/j.ecolmodel.2019.108741.

Díaz-Yáñez O., Mola-Yudego B., Ramón González-Olabarria J.R., Pukkala T. 2017. How does forest composition and structure affect the stability against wind and snow? For. Ecol. Manage., 401: 215-222.

Dobbertin M. 2002. Influence of stand structure and site factors on wind damage comparing the storms Vivian and Lothar. For. Snow. Landsc. Res., 77: 187-205.

Drouineau S., Laroussinie O., Birot Y., Terrasson D., Formery T., Roman-Amat B. 2000. Joint evaluation of storms, forest vulnerability and their restoration. Discussion paper. European Forest Institute (EFI) (9).

Faber P.J. 1975. Stability of stands to wind: A theoretical approach. Ned. Bosbouwtijdschr., 47: 179-193.

Forsell N., Wikström P., García F., Sabbadin R., Blennow K., Eriksson L.O. 2011. Management of the risk of wind damage in forestry: A graph-based Markov decision process approach. Ann. Oper. Res., 190, 57-74.

Galinski W. 1989. A windthrow-risk estimation for coniferous trees. Forestry, 62: 139-146.

Gardiner B.A., Stacey G.R., Belcher R.E., Wood C.J. 1997. Field and wind tunnel assessments of the implications of respacing and thinning for tree stability. Forestry, 70 (3): 233-252. 
Gregow H., Peltola H., Laapas M., Saku S., Venäläinen A. 2011. Combined occurrence of wind, snow loading and soil frost with implications for risks to forestry in Finland under the current and changing climatic conditions. Silva Fennica, 45 (1): 35-54.

Griess V.C., Knoke T. 2011. Growth performance, windthrow, and insects: meta-analyses of parameters influencing performance of mixed-species stands in boreal and northern temperate biomes. Can. J. Res., 41, 1141-1159. https://doi.org/10.1139/x11-042.

Haarsma R.J., Hazeleger W., Severijns C., Vries, H., Sterl A., Bintanja R., Oldenborgh G.J., Brink H.W. 2013. More hurricanes to hit Western Europe due to global warming. Geophys. Res. Lett., 40 (9): 1783-1788.

Hanewinkel M., Breidenbach J., Neef T., Kublin E. 2008. 77 years of natural disturbances in a mountain forest area - the influence of storm, snow and insect damage analysed with a longterm time-series. Can. J. For. Res., 38: 2249-2261.

Hanewinkel M., Kuhn T., Bugmann H., Lanz A., Brang P. 2014. Vulnerability of uneven-aged forests to storm damage. Forestry, 87: 525-534. https://doi.org/10.1093/forestry/cpu008.

Heinonen T., Pukkala T., Ikonen V.P., Peltola H., Dupont S. 2009. Integrating the risk of wind damage into forest planning. For. Ecol. Manage., 258 (7): 1567-1577.

Heinonen T., Pukkala T., Ikonen V.P., Peltola H., Gregow H., Venäläinen A. 2011. Consideration of strong winds, their directional distribution and snow loading in wind risk assessment related to landscape level forest planning. For. Ecol. Manage., 261: 710-719.

Jaworski A. 2013. Hodowla lasu. Pielegnowanie lasu. PWRiL, Warszawa.

Jaworski A. 2018. Hodowla lasu. Sposoby zagospodarowania, odnawianie lasu, przebudowa i przemiana drzewostanów. PWRiL, Warszawa.

Jelonek T., Walkowiak R., Jakubowski M., Tomczak A. 2013. Analiza wskaźników stabilności drzew w drzewostanach sosnowych uszkodzonych przez wiatr. Sylwan, 157 (5): 323-329.

Johann K. 1981. Nicht Schnee, sondern falsche Bestandsbehandlung versacht Katastrophen. Allgemeine Forstzeitung, 92: 163-171.

Jönsson A.M., Bärring L. 2011. Future climate impact on spruce bark beetle life cycle in relation to uncertainties in regional climate model data ensembles. Tellus A, 63: 158-173. doi:10.1111/ j.1600-0870.2010.00479.x.

Kangas E. 1959. Lumenmurrot ja metsänhoito. Metsätaloudellinen aikakauslehti. 1.

Kaźmierczak K., Pazdrowski W., Mańka K., Szymański M., Nawrot M. 2008. Kształtowanie się smukłości pni dębu szypułkowego (Quercus robur L.) w zależności od wieku drzew. Sylwan, 152 (7): 39-45.

Kenk G., Guehne S. 2001. Management of transformation in central Europe. For. Ecol. Manage., 151, 107-119. https://doi.org/10.1016/S0378-1127(00)00701-5.

Konôpka J. 1977. Vplyv rastových vlasnosí smreka na odolnost' lesných porastov proti vetru v oblasti Nizkych Tatier. Polnohosp. veda, 1.

Korzeniewicz R., Borzyszkowski W., Szmyt J., Kaźmierczak K. 2016. Smukłość 30-letniego niepielegnowanego drzewostanu brzozy brodawkowatej (Betula pendula Roth.) Acta Sci. Pol., ser. Silv. Colendar. Ratio Ind. Lignar. 15 (2): 79-86.

Korzeniewicz R., Pikliński P., Niedbała G., Adamski M., Piekutowska M., Kaźmierczak K. (2019). Smukłość modrzewia (Larix decidua Mill.) w 30-letnim niepielęnowanym drzewostanie i jej związek $z$ wybranymi cechami biometrycznymi. Nauka Przyr. Technol., 13, 1, 23-32. http:// dx.doi.org/10.17306/J.NPT.00262

Lohmander P., Helles F. 1987. Windthrow probability as a function of stand characteristics and shelter. Scand. J. For. Res., 2: 227-238.

Marini L., Lindelöw Å., Jönsson A.M., Wulff S., Schroeder L.M. 2013. Population dynamics of the spruce bark beetle: a long-term study. Oikos. DOI: 10.1111/j.1600-0706.2013.00431.x. 
Martín-Alcón S., González-Olabarria J.R., Coll L. 2010. Wind and snow damage in the Pyrenees pine forests: effect of stand attributes and location. Silva Fennica, 44 (3): 399-410.

Mason W.L. 2002. Are irregular stands more windfirm?. Forestry, 75: 347-355.

Meilby H., Niels Strange N., Thorsen B.J. 2001. Optimal spatial harvest planning under risk of windthrow. For. Ecol. Manage., 149 (1-3): 15-31.

Meng J., Bai Y., Zeng W., Wu Ma W. 2017. A management tool for reducing the potential risk of windthrow for coastal Casuarina equisetifolia L. stands on Hainan Island, China. Eur. J. Forest. Res., 136: 543-554. DOI 10.1007/s10342-017-1053-4.

Mitchell S.J. 2000. Stem growth responses in Douglas-fir and Sitka spruce following thinning: implications for assessing wind-firmness. For. Ecol. Manage., 135: 105-114.

Mitchell S.J., Hailemariam T., Kulis Y. 2001. Empirical modeling of cutblock edge windthrow risk on Vancouver Island, Canada, using stand level information. For. Ecol. Manag., 154: 117-130.

Nielsen C.C.N. 1995. Recommendations for stabilisation of Norway spruce stands based on ecological surveys. In: Wind and trees. Eds. M.P. Coutts, J. Grace. Cambridge University Press, Cambridge, 1279: 424-435.

Oliveira A.M. 1987. The H/D ratio in maritime pine (Pinus pinaster) stands. In: Proceedings of the IUFRO Conference, vol. 2. Forest Growth Modelling and Prediction, 23-27 August 1987, Minneapolis, Minn. Ed. A.R. Ek, S.R. Shifley, T.E. Burk. International Union of Forest Research Organizations, Vienna, 881-888.

Orzeł S. 2007. A comparative analysis of slenderness of the main tree species of the Niepolomice Forest. Electron. J. Pol. Agric. Univer. Series Forestry 10 (2).

Päätalo M.-L., Peltola H., Kellomäki S. 1999. Modelling the risk of snow damage to forests under short-term snow loading. For. Ecol. Manage., 116: 51-70.

Pasztor F., Matulla C., Zuvela-Aloise M., Rammer W., Lexer M.J. 2015. Developing predictive models of wind damage in Austrian forests. Annals of Forest Science 72: 289-301. https://doi. org/10.1007/s13595-014-0386-0.

Peltola H., Nykäinen M.-L., Kellomäki S. 1997. Model computations on the critical combination of snow loading and windspeed for snow damage of scots pine, Norway spruce and Birch sp. at stand edge. For. Ecol. Manage., 95: 229-241.

Peltola H., Kellomäki S. 1993. A mechanistic model for calculating windthrow and stem breakage at stand edge. Silva Fennica 27 (2): 99-111.

Perttilä P. 1987. Myrskyja lumituhojen esiityminen sähkölinjoilla. Inventointi ja käsittelyohjeet. MSc thesis. University of Helsinki, Helsinki.

Petty J., Swain C. 1985. Factors influencing stem breakage of conifers in high winds. Forestry, 58 (1): 75-84.

Petty J.A., Worrell R. 1981. Stability of coniferous tree stems in relation to damage by snow. Forestry, 54 (2): 115-128.

Pukkala T., Laiho O., Lähde E. 2016. Continuous cover management reduces wind damage. For. Ecol. Manage., 372: 120-127.

Rymer-Dudzińska T. 1992. Zależność średniej smukłości drzew w drzewostanach sosnowych od różnych cech taksacyjnych drzewostanu. Sylwan, 136 (12): 19-25.

Quine C.P. 2003. Wind-driven gap formation and gap expansion in spruce forests of upland Britain. In: Wind effects on trees. Proceedings of the International Conference, University of Karlsruhe, Karlsruhe, 16-18 September. Ed. B. Ruck et al., 101-108.

Quine C., Coutts M., Gardiner B., Pyatt G. 1995. Forests and wind: Management to minimize damage. Bulletin, 114. London.

Rottmann M. 1986. Wind- und Sturmschaden im Wald. Beitrage zur Beurteilung der Bruchgefahrdung, zur Schadensvorbeugung und zur Behandlung sturmgeschadigter Nadelholzbestande. J.D. Sauerläinder's Verlag, Frankfurt am Main. 
Rottmann M. 1985. Schneebruchschäden in Nadelholzbestäinden. Beiträige zur Beurteilung der Schneebruchgefäihrdung, zur Schadensvorbeugung und zur Behandlung schneegeschäidigter Nadelholzbestäinde. J.D. Sauerländer's Verlag, Frankfurt am Main.

Schelhaas M.J. 2008. The wind stability of different silvicultural systems for Douglas-fir in the Netherlands: A model-based approach. Forestry, 81 (3): 399-414.

Schelhaas M.J., Kramer K., Peltola H., van der Werf D.C., Wijdeven S.M.J. 2007. Introducing tree interactions in wind damage simulation. Ecological Modelling 207 (2-4): 197-209.

Schuck A., Schelhaas M.-J. 2013. Storm damage in Europe - and overview. In: Living with storm damage to forests. What Science Can Tell Us 3. Eds. B. Gardiner, A. Schuck, M.-J. Schelhaas, C. Orazlo, K. Blennow, B. Nicoll. European Forest Institute, 15-23.

Schütz J.P., Gotz M., Schmid W., Mandallaz D. 2006. Vulnerability of spruce (Picea abies) and beech (Fagus sylvatica) forest stands to storms and consequences for silviculture. Eur. J. Forest Res., 125 (3): 291-302.

Skrzyszewski J. 1993. Kształtowanie się zależności pomiędzy żywotnościa, cechami morfologicznymi korony i masa systemu korzeniowego a przyrostem promienia na pierśnicy świerka i modrzewia. Rozprawa doktorska, Kraków.

Vacchiano G., Justin Derose R., Shaw J.D., Svoboda M., Motta R. 2013. A density management diagram for Norway spruce in the temperate European montane region. Eur. J. Forest Res., 132: 535-549. DOI 10.1007/s10342-013-0694-1.

Valinger E., Fridman J. 2011. Factors affecting the probability of windthrow at stand level as a result of Gudrun winter storm in southern Sweden. For. Ecol. Manage., 262: 398-403. https:// doi.org/10.1016/j.foreco.2011.04.004.

Valinger E., Lundqvist L., Brandel G. 1994. Wind and snow damage in a thinning and fertilisation experiment in Pinus sylvestris. Scan. J. Forest Res., 9: 129-134.

Wang Y., Titus S.J., LeMay V.M. 1998. Relationships between tree slenderness coefficients and tree or stand characteristics for major species in boreal mixedwood forests. Can. J. For. Res., 28: $1171-1183$.

Wilson J.S., Oliver C.D. 2000. Stability and density management in Douglas-fir plantations. Can. J. For. Res., 30: 910-920.

Zajączkowski J. 1991. Odporność lasu na szkodliwe działanie wiatru i śniegu. Świat, Warszawa.

Zeng H., Pukkala T., Peltola H. 2007. The use of heuristic optimisation in risk management of wind damage in forest planning. For. Ecol. Manage., 241: 189-199.

\section{WYKORZYSTANIE WSPÓŁCZYNNIKA SMUKŁOŚCI W DIAGNOZOWANIU ZAGROŻEŃ SZKÓD OD WIATRU}

\section{STRESZCZENIE}

Odporność (lub jej brak) na szkody od wiatru jest związana z indywidualnymi cechami drzewa i drzewostanu, takimi jak gatunek drzewa, wysokość, pierśnica, wielkość koron, zagęszczenie, struktura wysokościowa, przestrzenne rozmieszczenie luk, głębokość ukorzeniania, wielkość systemu korzeniowego i rozmieszczenie korzeni kotwiczących oraz z występowaniem zgnilizny korzeni lub pni (Zajączkowski 1991, Valinger i Fridman 2011, 
Albrecht i in. 2012, Hanewinkel i in. 2014, Pasztor i in. 2015, Pukkala i in. 2016). Każda z wymienionych cech pojedynczego drzewa (długość korony, smukłość i wielkość systemu korzeniowego) jednostkowo wpływa na stabilność drzewa i może być kształtowana w ramach prac pielęgnacyjnych. Odporność jest zależna również od cech glebowo-orograficznych, takich jak: wilgotność gleby (Mitchell i in. 2001), ekspozycja w stosunku do przeważających wiatrów i nachylenie, wysokość n.p.m., oraz cech sąsiadujących drzewostanów (różnice wieku i wysokości) (Mitchell i in. 2001, Albrecht i in. 2012, Hanewinkel i in. 2014, Pasztor i in. 2015).

W badaniach nad odpornością drzew i drzewostanów na niszczące działanie wiatru i śniegu powszechnie wykorzystywany jest współczynnik smukłości (Abetz 1976, za: Jaworski 2013, Burschel i Huss 1997). Jest to syntetyczny wskaźnik określający kształt pnia (zbieżystość pnia, która jest odwrotnością smukłości). Współczynnik smukłości oblicza się przez podzielenie wysokości $(\mathrm{H})$ przez pierśnicę $(\mathrm{D})$. Im większą pierśnicę posiada drzewo przy tej samej wysokości (niższe wartości H/D), tym potrzeba większej siły do wygięcia jego pnia. Niski współczynnik smukłości związany jest z dłuższą koroną, niższym położeniem środka ciężkości i lepiej rozwiniętym systemem korzeniowym, ze względu na większą przestrzeń wzrostu. Swobodny rozwój korony sprzyja zwiększeniu przyrostu pierśnicy i zwiększaniu zbieżystości drzewa (Petty i Worrell 1981). Zwiększenie przestrzeni wzrostu koron ogranicza również ich asymetryczny rozwój (Petty i Swain 1985, Valinger i in. 1994), a drzewa o regularnych koronach są mniej podatne na wychylenia (np. pod asymetrycznym obciążeniem przez śnieg). W mniejszym stopniu obserwuje się również występowanie momentu skręcającego. Korzenie drzew rozluźnionego drzewostanu mocniej zakotwiczają się w glebie, co prowadzi do zwiększenia odporności na wywały (Nielsen 1995). Peltolai in. (1997) wyjaśniają, że przy niskim współczynniku smukłości śnieg jest zrzucany z koron drzew przez podmuchy wiatru i nie dochodzi do kumulacji tych dwóch czynników szkodotwórczych.

W części publikacji autorzy przyjmują współczynnik smukłości jako miarę stabilności drzew/drzewostanów. Formułują wnioski i oceny co do zasad pielęgnacji drzewostanu, zakładając, że niższe wartości H/D będą skutkowały większą odpornością na wiatr i śnieg (Rymer-Dudzińska 1992, Wang i in. 1998, Wilson i Oliver 2000, Orzeł 2007, Kaźmierczak i in. 2008, Korzeniewicz i in. 2016, 2019). Inne podejście metodyczne to tworzenie modeli pozwalających na predykcję faktu wystąpienia szkody od wiatru lub prawdopodobieństwa jej wystąpienia. W modelach tych współczynnik smukłości jest jedną z wielu zmiennych. Analiza skuteczności, miar dopasowania, możliwości predykcyjnych i klasyfikacyjnych tych modeli wskazuje, że współczynnik smukłości jako pojedyncza zmienna ma często relatywnie małą wartość jako zmienna wyjaśniająca. W badaniach Pukkala i in. (2016) zmienna współczynnik smukłości okazała się użyteczna, ale tylko w interakcji z określonym poziomem pola pierśnicowego przekroju drzewostanu. W publikacji Martín-Alcón i in. (2010) wpływ na predykcję procentu uszkodzonych drzew w drzewostanie miał współczynnik smukłości, ale podzielony przez pole przekroju drzewostanu. Sama smukłość nie jest dobrym wskaźnikiem stabilności drzewostanu, potrzebny jest również wskaźnik wzajemnego wspierania się drzew w obrębie drzewostanu (Schütz i in. 2006, Schelhaas i in. 2007, Martín-Alcón i in. 2010). W publikacji Albrecht i in. (2012) stwierdzono, że łącznie z H/D powinna być uwzględniana zmienna wysokość drzewa. Krytycznie oceniono również przydatność współczynnika smukłości jako predyktora w badaniach obejmujących dane historyczne. Oliverira (1987) i Schütz i in. (2006) również nie rekomendują wykorzystania wskaźnika H/D jako pojedynczej zmiennej będącej predyktorem odporności na szkody od wiatru. W publikacji Díaz-Yáñez i in. (2019), 
w najlepszych pod względem predykcyjnym modelach, współczynnik smukłości miał udział w wyjaśnianiu prawdopodobieństwa uszkodzeń poniżej 10\%. Wysokość drzew wyjaśniała większą część prawdopodobieństwa wystąpienia uszkodzenia.

Ze względu na powszechne wykorzystanie współczynnika smukłości jako miary (wskaźnika) odporności na szkody od wiatru wielu autorów podaje jego pożądane/krytyczne wartości. W Niemczech Abetz (1987) zalecał wartość współczynnika smukłości około 80 jako właściwą dla świerka pospolitego. W podręczniku Burschel i Huss (1997) dla gatunków iglastych autorzy przyjęli następującą skalę wartości: bardzo niestabilne (H/D > 100), niestabilne (H/D 80-100), stabilne (H/D < 80), drzewa rosnące pojedynczo $(\mathrm{H} / \mathrm{D}<45)$. Wartości podawane przez innych autorów są zbliżone (Cremer i in. 1982, Lohmander i Helles 1987, Johann 1981 i Rottmann 1985, za: Peltola i in. 1997, Becquey i Riou-Nivert 1987, za: Wilson i Oliver 2000).

Wilson i Oliver (2000) w podsumowaniu swych badań stwierdzają, że nie ma jednej wartości H/D gwarantującej stabilność. Jest ona zależna od siły wiatru. Nie jesteśmy w stanie całkowicie wyeliminować zagrożenia od wiatru, a obniżanie H/D prowadzi do zmniejszenia wartości lub kosztów (podkrzesywanie) produkcji. Skrzyszewski (1993) stwierdził, że promowanie podczas trzebieży drzew (świerk pospolity) o niskim współczynniku smukłości (poniżej 80) prowadzi do powstania drzewostanów złożonych z drzew nisko ugałęzionych z dużym udziałem sęków wrośniętych oraz o bardzo zbieżystym pniu i szerokich słojach, co u gatunków iglastych skutkuje niską wytrzymałością mechaniczną i obniżoną trwałością drewna. Bezpieczne strategie to luźniejsza więźba sadzenia i/lub silne cięcia w młodym wieku (młodnik, żerdziowina), a w drzewostanach zaniedbanych bardzo słabe cięcia w wielu nawrotach. Alternatywą może być hodowla drzewostanów przerębowych (Dobbertin 2002, Griess i Knoke 2011, Jaworski 2013, Hanewinkel i in. 2014, Pukkala i in. 2016).

Wartość współczynnika smukłości jest skutkiem (efektem, pochodną) określonej budowy piętrowej drzewostanu (struktury), jego wieku (wysokości) i stopnia zagęszczenia oraz zabiegów wykonanych w przeszłości. Cytowane wcześniej publikacje wskazują, że współczynnik smukłości powinien być analizowany w kompleksie z innymi zmiennymi (składem gatunkowym, strukturą i zagęszczeniem drzewostanu oraz siedliskiem, wilgotnością gleby, ekspozycją, nachyleniem, wysokością n.p.m. i wiekiem oraz wysokością sąsiadujących drzewostanów).

\section{SŁOWA KLUCZOWE}

współczynnik smukłości • wiatrołomy • szkody od śniegu i wiatru • modelowanie zagrożeń 